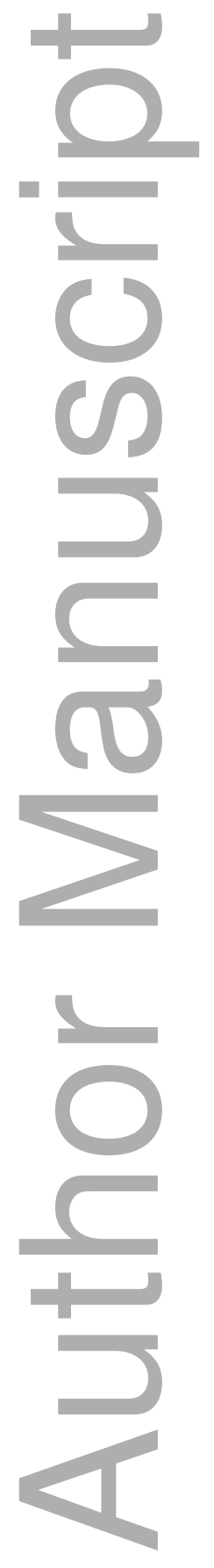

This is the author manuscript accepted for publication and has undergone full peer review but has not been through the copyediting, typesetting, pagination and proofreading process, which may lead to differences between this version and the Version of Record. Please cite this article as doi: $\underline{10.1111 / i e j .12772}$

This article is protected by copyright. All rights reserved 
DR. SOK-JA JANKET (Orcid ID : 0000-0003-0078-3992)

Received Date : 30-Nov-2016

Revised Date : 15-Mar-2017

Accepted Date : 19-Mar-2017

Article type :Original Scientific Article

\section{Lower risk for cardiovascular mortality for patients with root filled teeth in a Finnish population}

J H. Meurman ${ }^{1}$, S-J Janket ${ }^{2}$, M Surakka $^{3}$; E A. Jackson ${ }^{4}$, L K. Ackerson ${ }^{5}$, H R Fakhri ${ }^{2}$, S Chogle $^{6}$, A Walls ${ }^{7}$

${ }^{1}$ Department of Oral and Maxillofacial Diseases, Helsinki University Hospital and University of Helsinki, Helsinki, Finland, ${ }^{2}$ Center for Clinical research, General Dentistry, and Department of Periodontology, Boston University H. M. Goldman School of Dental Medicine, Boston, MA, USA, ${ }^{3}$ Otorhinolaryngology/Maxillofacial Surgery, Kuopio University Hospital, Kuopio, Finland, ${ }^{4}$ Preventive Cardiology, Internal Medicine, University of Michigan, Ann Arbor, Michigan, USA; ${ }^{5}$ Public Health, University of Massachusetts, Lowell, MA, USA, ${ }^{6}$ Endodontics, Boston University, H. M. Goldman School of Dental Medicine, Boston, MA, USA; ${ }^{7}$ Edinburgh Dental Institute, University of Edinburgh, Scotland, United Kingdom.

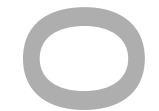

Running title: Root canal treatment and lower CVD mortality

Key words: pulpitis; endodontic treatment; coronary artery disease; C-reactive protein; cardiovascular mortality.

\section{Correspondence:}

Sok-Ja Janket

Center for Clinical research, General Dentistry, and Department of Periodontology, Boston University H. M. Goldman School of Dental Medicine, Boston, MA, USA;

This article is protected by copyright. All rights reserved 
Email: skjanket@bu.edu

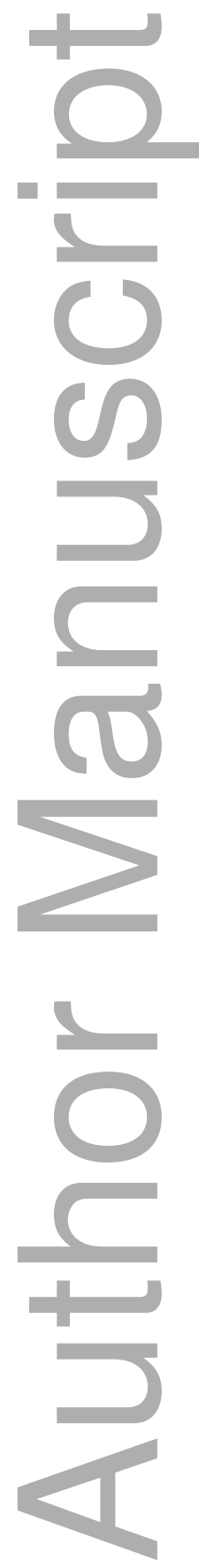

This article is protected by copyright. All rights reserved 


\section{Abstract}

Aim To investigate the relationship of radiographic evidence of root filled teeth to cardiovascular outcomes.

Methodology Baseline data for 506 subjects including 256 angiographically verified heart disease patients and 250 matched cardiologically healthy controls participating in the Kuopio Oral Health and Heart study were collected in 1995-1996. Cardiovascular disease (CVD) mortalities were accrued until May $31^{\text {st }} 2015$ and appended to the baseline data. Mortality status data were obtained from the Finnish National Death Register where all mortality cases and the causes of death are compiled for all Finnish citizens. Of the 506 participants, 473 subjects who had no missing values in the predictor, outcome or confounding factors were included in the analyses to assess the relationship of radiographic evidence of root filled teeth with prevalent coronary artery disease (CAD) cross-sectionally and also with CVD mortality longitudinally. Multivariable logistic regression was used for the cross-sectional part and proportional hazard regression analyses for the longitudinal part of the study adjusting for age, sex, smoking, edentulism, diabetes, hypertension, total/HDL cholesterol ratio, and income. Additionally, whether this association was independent of periodontitis, and a systemic marker of inflammation, serum C-reactive protein (CRP) was examined.

Results: Having $\geq 1$ root filled teeth was associated with $84 \%$ lower odds of prevalent CAD with Odds Ratio $(\mathrm{OR})=0.16,95 \%$ confidence interval $(\mathrm{Cl}) 0.09-0.28, P<0.0001$. The OR for edentulism was 1.32 $(\mathrm{Cl}: 0.73-2.38), P=0.36$, suggesting a non-significant increase in risk. Prospectively, having at least one root filled teeth was associated with a $49 \%$ lower risk of CVD mortality (hazard ratio $[\mathrm{HR}]=0.51, \mathrm{Cl}=0.27$ $0.97, P=0.04)$ while edentulism was associated with non-significantly increased risk for CVD mortality: $\mathrm{HR}=1.25(\mathrm{Cl}: 0.65-2.42), P=0.36$. Adjustment for periodontitis or serum CRP levels changed the OR or HR slightly but the associations remained significant.

Conclusions Having $\geq 1$ root filled teeth was associated with significantly lower odds for prevalent CAD cross-sectionally and lower risk of cardiovascular mortality prospectively. These reduced associations with CVD were independent of periodontitis or serum CRP levels.

This article is protected by copyright. All rights reserved 


\section{Introduction}

Chronic oral infections including periodontitis (Beck et al. 1996) have been associated with increased risk of CVD and a healthy dentition as a marker for reduced past oral infections has been associated with a significantly lower risk of CVD mortality (Janket et al. 2014). Acute infections (Corrales-Medina et al. 2013) including upper and lower respiratory tract infections are established risk factors for acute coronary syndrome (Hao et al. 2013). In acute infections, bacterial toxins may activate the innate immune system (Hotchkiss et al. 2003) and initiate intravascular inflammation and thrombosis and consequently may contribute to cardiac events (Cotti et al. 2011).

The microorganisms in advanced dental caries cause pulpitis that can lead to irreversible pulpitis and pulp necrosis with apical periodontitis that elicits systemic inflammatory responses (Gomes et al. 2013). Such inflammatory responses are risk factors for the development of atherosclerosis and CVD outcomes (Gomes et al. 2016, Pasqualini et al. 2012, Petersen et al. 2014). Early root canal infection is dominated by Gram-positive microbiota comprising approximately $69 \%$ followed by Gram-negative bacteria (27\%), and fungi (Kouchi et al. 1980, Love et al. 2002). In addition to the Gram negative anaerobes native to the infected root canal system (Bae et al. 1997), necrotic pulp tissue can become coinfected with periodontal pathogens (Liljestrand et al. 2016) through lateral canals and denuded dentine surfaces with non-vital pulp (Jansson 2015). Avoiding discomfort from advanced dental caries is the most important priority for many patients (Stoller et al. 2004), and extraction of the offending tooth is often chosen by the patients as a preferred treatment option. But this decision is based on non-dental factors such as patient/family requests or finances (Johnson 1993). However, extraction can affect subsequent nutritional intake (Janket et al. 2008, Nowjack-Raymer et al. 2003, Savoca et al. 2010) and the adverse effects of edentulism on health have been well substantiated (Brown 2009). However, no previous studies have compared adverse outcomes of edentulism to saving teeth by root canal treatment. The adverse effects of edentulism on CVD was estimated by separating the edentulous group. In this cohort $60 \%$ of extractions were reported to be due to advanced dental caries and $40 \%$ were due to periodontitis, aesthetic reasons, or trauma. Inflamed pulpal tissue or periradicular tissue expresses interleukin-6 (IL-6) (Euler et al. 1998). Additionally, interleukin-1 $\alpha$ and IL-1 $\beta$ are expressed by polymorphonuclear leukocytes in the periradicular tissue (Miller et al. 1996). Because these cytokines play major roles in the 
pathogenesis of CVD (Bujak et al. 2009, Gomes et al. 2013, 2016, Volpato et al. 2001), it was postulated that root fillings will reduce IL- 6 or IL-1 $\beta$ leading to decreased risk of future cardiovascular events.

Therefore, the aims of this study were to investigate whether:

1. The radiographic evidence of root fillings at baseline would be associated with decreased risk of prevalent coronary artery disease (CAD) cross-sectionally and with reduced CVD mortality longitudinally;

2. Concurrent Periodontitis will affect the association between root fillings and CVD.

Periodontitis has been reported as a contributing factor to CVD and some study participants had both periodontitis and root fillings. Thus, periodontitis is another source of inflammation that may contribute to atherosclerosis. Therefore, the inflammatory burden from periodontitis was controlled to establish the independent contribution of inflammation reduction from root fillings on CVD mortality.

3. Systemic inflammation measured by CRP would affect the association of root fillings and CVD outcomes. CRP has been an independent predictor for CVD (Ridker et al. 1998) and the contribution of oral infection to CVD was mediated in part via CRP (Janket et al. 2014). Therefore, oral inflammation and CRP are in a confounding relationship. Whether the contribution of reduced inflammation from root fillings to CVD outcomes is independent of CRP were examined.

\section{Materials and methods}

\section{Ethical consideration and human subjects' protection}

This study was approved by the Joint Ethical Committee of the Kuopio University Hospital and the University of Kuopio. Written informed consent was obtained from all participants. The longitudinal portion of the study was approved by the Boston University Institutional Review Board. This project adhered to the guidelines set forth by the Declaration of Helsinki and the Belmont Accord to assure the safety of human research subjects.

\section{Study population}

This article is protected by copyright. All rights reserved 
Kuopio Oral Health and Heart (KOHH) study was initiated as a case-control study in 1995-1996, to investigate the association between oral health and CAD in Kuopio, Finland. For the current study, mortality data (median follow-up of 18.8-years) was appended to the baseline data to create a prospective follow-up study assessing CVD mortality. At baseline 256 consecutive patients attending Kuopio University Hospital coronary angiography unit and with a confirmed diagnosis of CAD were invited to participate in the $\mathrm{KOHH}$ study. The CAD diagnosis was made by the presence of at least $50 \%$ stenosis in one of the epicardial arteries. Also, 250 age- and gender-matched controls were recruited from the general surgery or otorhinolaryngology departments at the same hospital for elective surgery. They were considered as not having heart disease based on their medical history and electrocardiogram taken during the pre-admission tests. The controls were representative of the population of the same catchment area where the cases arose. The same exclusion and inclusion criteria were applied to the control subjects. Potential subjects who had taken antibiotics during the previous 30 days or had chronic infection other than dental disease were excluded. Additional exclusion criteria for the CAD group were: (a) those who needed emergency coronary by-pass surgery or valvular replacement surgery; (b) those whose disease status was so grave that a dental examination or dental x-ray could not be performed safely; and (c) those who were deemed to require antibiotic prophylaxis prior to periodontal probing at the time of baseline data collection. Further details regarding this cohort have been published elsewhere (Janket et al. 2010, 2014).

\section{Ascertainment of the endpoints}

The outcome, CVD mortality, was assessed using the mortality records obtained from the Finnish Death Registry in 2009, 2010, 2011, 2014, and 2015. The World Health Organization International Classification of Diseases (ICD)-10 codes 100 through 199 were considered deaths due to cardiac causes and the most prevalent one was I25 (chronic ischaemic heart disease). Each resident of Finland has a unique identifier number and the Office of Statistics Finland collects all health data including mortality. The reliability of mortality data was determined to be $99 \%$ after comparing 2009 and 2011 records in a random sample of 100 records. The validity of the mortality records was tested by comparing them to the physician's diagnosis of death from the subjects' medical records. Three disagreements in ICD-10 codes were found in 100 randomly examined records, but upon further detailed investigation, all turned out to be in 
agreement. For example, one case the Finnish Death Registry listed as "I21.4: Acute subendocardial myocardial infarction" while the physician's diagnosis of death was "I25.1 Atherosclerotic heart disease". Although ICD-10 codes were different, they described the similar pathology. Thus, validity was judged to be excellent. These facts were published previously (Janket et al. 2014).

\section{Exposure assessment}

At the initiation of this study (1995-1996), a single examiner (MS) performed all clinical dental examinations and pantomographic readings according to the World Health Organization format. Pantomographic evidence of root fillings was enumerated by the images of the radiopaque root filling for each patient. The two pantomogram readings by this examiner (MS) exhibited an excellent agreement (kappa=0.9). Edentulous subjects who could not have root fillings were separately categorized from the root filling assessment. There was one person who was edentulous but had root fillings. This was presumed to be a case of an overdenture where root fillings were provided to improve denture retention. The details of clinical oral examination including number of teeth, amount of vertical bone loss (measured from cemento-enamel junction in $\mathrm{mm}$ ), calculus deposits, and restorations with overhangs as well as salivary immunoglobulins were measured and the results were reported previously (Janket et al. 2004, Qvarnstrom et al. 2008).

\section{Assessment of covariates}

Baseline behavioral and demographic factors were assessed and the results were published elsewhere (Janket et al.2010, Qvarnstrom et al. 2010). Briefly, age in years and smoking in three categories (neversmokers, current smokers and past smokers) were assessed. Body mass index (BMI) was calculated by weight in $\mathrm{kg}$ divided by squared height in meters. Total cholesterol (TC), triglyceride (TG), and highdensity lipoprotein cholesterol (HDL) were measured by the automated enzymatic technique. Low density lipoprotein ( $\mathrm{LDL}$ ) cholesterol levels were estimated by the Friedewald formula. Hypertension and diabetes were ascertained by medical record review by one of the authors (MS). Subjects were categorized as hypertensive or diabetic if their medical records documented these diagnoses or they received treatments. Periodontitis was categorized using the updated periodontitis definition by which more than one site with probing depth $\geq 5 \mathrm{~mm}$ indicates periodontitis(Eke et al. 2012). CRP was measured by immuno-turbidimetry utilizing the HITACHI 717 analyzer (Boehringer Mannheim, Mannheim, Germany). 


\section{Statistical analyses}

Out of the original cohort of 506 subjects, 33 were excluded from the analyses because of missing values in the outcomes, the predictors or the covariates. Thus, using SAS version 9.3, basic characteristics such as age, gender, smoking status, BMI, number of teeth and cholesterol levels were compared in 473 subjects without any missing values stratified by root filling status. There were 117 edentuous subjects, and among the 356 dentate subjects 160 had radiographic evidence of root fillings while 196 did not. In the bivariate analyses, Fisher's exact or non-parametric tests were used. In multivariate analyses, logistic regression was used in the cross-sectional portion of the study to examine the association of prevalent $\mathrm{CAD}$ as the outcome with baseline root filling status as the exposure. In the longitudinal portion of the study, Cox proportional hazard modeling was performed after testing the proportional hazard assumption. The outcome in longitudinal analyses was mortality due to cardiovascular causes. The established confounding factors such as age at the entry to the study, gender, smoking (never, past, current), diabetes, hypertension, total cholesterol to HDL ratio (TC/HDL ratio), and personal income were controlled in both cross-sectional and longitudinal portions of the study. Whether concurrent periodontitis or systemic inflammation assessed by serum CRP levels would alter the association of root fillings with CVD mortality was also tested. Additionally, to test whether baseline CAD affects the relationship of root fillings and CVD mortality differentially (effect modification by baseline CAD), the interaction term between baseline CAD and root fillings was analysed. To assess whether affluence alters the relationship of root fillings and CVD mortality, income was controlled. Also the impact of confounding by a generally healthy lifestyle that may be concurrent with root fillings was tested utilizing sensitivity analyses in non-CVD mortality where inflammation may have lesser influence than CVD.

\section{Results}

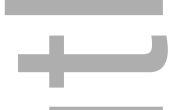

A total of 148 deaths in the cohort were accrued of which 90 were due to CVD. The leading non-CVD causes were cancer, followed by respiratory diseases and neurologic disorders such as Alzheimer's disease. The sample size was too small to analyze the data on non-CVD mortality.

The baseline characteristics stratified by CAD status are presented in Table 1. As expected, most established CVD risk factors were significantly more prevalent in the CAD group. Of the dental variables, 
number of remaining teeth and prevalence of periodontitis, were higher and the proportion of edentulism was lower in controls. Moreover, $53.6 \%$ of the control group had radiographic evidence of root fillings while only $14.5 \%$ had evidence of root fillings in the CAD group. In general, poor oral health was evident in CAD cases.

In multivariate analyses where age, gender, smoking, hypertension, diabetes, income and TC/HDL cholesterol ratio were adjusted, the edentate subjects were at increased odds of prevalent CAD, albeit non-significantly $(\mathrm{OR}=1.32,95 \% \mathrm{Cl}$ : [0.73 - 2.38], $p=0.36)$ compared with those who did not have evidence of root fillings. By contrast, those who had evidence of root fillings were at $84 \%$ lower odds of having prevalent CAD compared to those with no evidence of root fillings ( $\mathrm{OR}=0.16,95 \% \mathrm{Cl}: 0.09-0.28$, $p<0.0001)$. Controlling for periodontitis, which is a different source of oral inflammation, changed the OR slightly to 0.17 but the $p$-value remained highly significant $(p<0.0001)$. In this cohort, the prevalence of periodontitis was $22.6 \%$. Adjusting for either periodontitis or serum CRP levels did not materially alter the results $(O R=0.18, p<0.0001)$. The majority of the confounding variables were significantly associated with $C A D$. Nevertheless, root fillings remained significantly and inversely associated with prevalent $C A D$ even after adjusting for these confounders. These results are presented in Table 2.

In the longitudinal portion of the analyses, having at least one root filled tooth was associated with a $49 \%$ reduction in the risk of CVD mortality $(\mathrm{HR}=0.51,95 \% \mathrm{Cl}: 0.27-0.97, p=0.04)$ in multivariate analyses. The edentulous group was again at a non-significantly elevated risk of CVD mortality $(H R=1.27$, $95 \% \mathrm{Cl}:[0.77-2.11], \mathrm{p}=0.38)$. Similar to the results in the cross-sectional analyses, the adjustment of periodontitis or serum CRP levels did not materially alter the inverse association of root fillings and CVD mortality $(\mathrm{HR}=0.51,95 \% \mathrm{Cl}: 0.27-0.98, p=0.04)$. Unlike the results from cross-sectional analyses, the only risk factors significantly predictive of CVD mortality in addition to the radiographic evidence of root fillings were age, smoking, and hypertension. These results are presented in Table 3.

In the testing of effect modification by baseline CAD, the interaction was not a significant predictor for CVD mortality (HR=1.15, Cl: $0.55-2.43, p=0.71)$ adjusting for age, smoking and hypertension. To confirm this, the cohort was stratified by baseline CAD status and separate analyses conducted. The results showed a similar inverse relationship in both cases and controls albeit not significant due to 
sample size reduction ( $\mathrm{HR}=0.81$ in controls and $\mathrm{HR}=0.82$ in cases) confirming no interaction between baseline $\mathrm{CAD}$ and root fillings.

Although root fillings are considered an affluence-dependent intervention, adjusting for income did not materially alter the relationship of root fillings and CVD mortality. In a multivariable adjusted model, being in the top $25 \%$ of income was inversely associated with CVD mortality $(\mathrm{HR}=0.71,95 \% \mathrm{Cl}=$ $0.39-1.30)$ but this was not statistically significant $(p=0.21)$.

\section{Discussion}

Within the limitations of this study, radiographic evidence of root fillings was associated with a significantly lower risk of cardiovascular mortality after adjusting for established confounding factors. Moreover, this association was independent of baseline periodontitis or systemic inflammation measured by serum CRP levels. Additionally, baseline CAD did not influence the association of root fillings to CVD mortality.

In the cross-sectional analyses (Table 2), an association between poor oral health and CAD was evident but this association cannot be considered as a causal relationship. Rather, baseline characteristics may describe the state of oral health due to CAD. Age and gender in relation to CAD were the opposite of generally accepted knowledge that those who are younger or female are less prone to CAD in the general population. However, these young and female subjects in the cohort already had CAD at baseline and their increased risks are described in Table 2 .

On the contrary, the prospective results in Table 3 showed that individuals who were older or male were at increased risk for CVD mortality in agreement with generally accepted pattern of risk in CVD. This fact suggests that baseline CAD-related factors are not necessarily risk factors for CVD mortality prospectively. For example, the CRP levels which had strong association with prevalent CAD $(\mathrm{OR}=22)$ or the Total to HDL cholesterol ratio was not a significant predictor for CVD mortality.

Of the total CVD mortality ( $N=90), 69$ CVD deaths (77\%) occurred in the CAD group. Because nearly $80 \%$ of CVD mortality occurred in the baseline CAD group, it is reasonable to assume that baseline CAD is on the causal pathway to CVD mortality, and adjusting for an intermediate variable on the causal pathway to the end point of disease is not appropriate in epidemiology (Hennekens et al. 
1987). Such adjustment would actually bias the results and could even reverse the direction of the association (Cook 2011).

The postulated mechanism is that root fillings may reduce cytokine production such as IL-6 and/or IL- $\beta$ which increase atherosclerotic inflammation. However, it is possible that confounding by healthy lifestyle could be the reason for the apparent beneficial effects of root fillings. Therefore, a sensitivity analysis was performed to allay this concern for Hawthorn Effects by testing the relationship between root fillings and non-CVD mortality where inflammation may play a lesser role. Indeed, the results were not significant suggesting that a healthy lifestyle may not be the reason for the decreased CVD mortality. If the observed results were due to healthy lifestyle, the same beneficial effects would have been observed in non-CVD mortality.

Although previous studies suggested that a self-reported history of endodontic therapy increased the risk of incident CVD (Caplan et al. 2009), the precise estimation of inflammation from endodontic origin was difficult to measure (Caplan et al. 2006). To overcome this difficulty, the radiographic evidence of removal of inflammation from endodontic origin was assessed in the current study. While the exact data on the cause for the root fillings is not available, the highly significant correlation between the number of teeth with root fillings and the number of periapical lesions (apical periodontitis) appear to suggest that root fillings were typically rendered to treat apical periodontitis (Spearman correlation coefficient $=0.43, p=0.0001$.

This assumption appears to contradict the recent report by Huumonen and colleagues that apical periodontitis was more prevalent in root filled than non-root filled teeth (Huumonen et al. 2016). However, not all apical radiolucencies (typically assumed apical periodontitis) resolve posttreatment. In fact approximately $36 \%$ of post-treatment periapical radiolucencies remained unchanged in size or even increased after 12 months (Zhang et al. 2015). The reason for this is because not all periapical radiolucencies are pathologic apical periodontitis: some are scar tissues and others can be cysts or tumours (Garcia et al. 2007).Thus the prevalence of apical periodontitis does not translate well to CVD outcomes (Berlin-Broner et al. 2016) and some radiolucencies may not need root filling (Nair 2006). Moreover, if there were residual apical radiolucencies after root filling, the total inflammatory burden and subsequent risk of CVD would be much less in root filled teeth than in non-root filled teeth as reported by 
Liljestrand et al. (2016). These facts are corroborated by a report that apical periodontitis increased oxidative stress (Inchingolo et al. 2014) which is a risk factor for atherosclerosis (Kornfeld et al. 2015, Sugamura et al. 2011) and endodontic treatment reduced reactive oxygen species and increased antioxidant potential (Inchingolo et al. 2014). These are highly supportive of the hypothesis that root canal treatment will decrease the harmful effects generated by apical periodontitis and will therefore reduce the risk for CVD outcomes. In longitudinal analyses, age, smoking and hypertension were the independent and significant risk factors to CVD mortality. The close relationship of endodontic inflammation and hypertension were reported in a previous longitudinal study where the risk of incident hypertension was significantly increased $(\mathrm{RR}=2.0,95 \% \mathrm{Cl}=1.16-3.46)$ with the presence of apical periodontitis (Gomes et al. 2016).

The present cohort has been extended from a case-control study to a longitudinal form. As such, concerns for potential risk amplification due to the high prevalence of baseline CAD were raised (Sommerfelt et al. 2012). However, the simulated data have proven that the "time to event analyses" such as Cox proportional hazard regressions which use semi-non parametric method were unaffected by the high CAD proportion at baseline (Janket et al. 2014). Therefore, the results from the present study can be generalized to other populations. Nonetheless, future clinical trials in a CAD-free population are needed to confirm the findings.

Serum CRP can originate from two different sources: infection- or obesity-related inflammation. Metabolic inflammation is sterile, low grade inflammation observed in obesity, diabetes or atherosclerosis (Janket et al. 2015). Obesity and diabetes can increase intestinal permeability and cause spontaneous endotoxemia (Cani et al. 2007) reflected as an increased serum level of lipopolysaccharide (LPS) (Amar et al. 2008). LPS is a component of the Gram-negative bacterial cell wall. This is important because Gram-negative bacteria are the predominant pathogens in periodontitis, and periodontitis is associated with obesity and diabetes. Thus, metabolic inflammation and periodontitis are in a confounding relationship, and the impact of obesity-related metabolic inflammation has to be controlled to establish the independent contribution of periodontitis to CVD risk increase. As CRP which is largely a marker for metabolic inflammation (Gupta et al. 2012) has been controlled in the present study, the results are independent of metabolic inflammation.

This article is protected by copyright. All rights reserved 
Others reported that CRP levels were inversely associated with socioeconomic status (SES)(Kohler et al. 2013). The present data also show significant association between low income and increased CRP levels in a t-test but this did not translate to CVD mortality in the multivariable adjusted models. The current results from a Finnish cohort with uniformly high living standard are in agreement with other studies from Scandinavia reporting non-significant impact of SES on oral health and chronic diseases association(Cabrera et al. 2005).

\section{Strengths:}

Previous research considered self-reported history of endodontic therapy as a marker for inflammation (Caplan et al.2006, Joshipura et al. 2006). However, assessing inflammation from self-report may not be reliable as the authors stated (Caplan et al. 2006). This difficulty was avoided by assessing the radiological proof of root fillings which is one of the strengths. A long follow-up (median =18.8 years) and precise dental examination given at baseline are additional strengths of the present study because precise dental measurements increase the fidelity of the results.

\section{Limitations:}

As shown in Table 1, those who did not opt for root fillings have fewer remaining teeth. This indirectly suggests that these individuals might have chosen extraction rather than root canal treatment.

Unfortunately, information regarding the cause for the fewer remaining teeth is not available. It has been presumed that edentulism results from severe cases of dental infection/inflammation leading to significant adverse outcomes (Lee et al. 2006). In the present study where dentate groups were divided by root filling status as well as edentulism, edentulism was not a significant risk factor for CVD outcomes ( $p$ $=0.34$ ) due to small sample sizes resulting from stratification. However, when the edentulous group was compared to the dentate group without stratifying by root filling status, a significant association of edentulism to CVD mortality ( $\mathrm{HR}=1.63[\mathrm{Cl}: 1.02-2.60] ; p=0.04)$. This is consistent with the previous reports showing detrimental consequences of edentulism (Brown 2009, Osterberg et al. 2007).

\section{Conclusion}

Within the limitations of this study, radiographic evidence of root fillings was significantly associated with lower odds for prevalent CAD at baseline and reduced risk of CVD mortality longitudinally controlling for 
established confounders. These results suggest that root fillings may be associated with reduced CVD risk. However, the residual confounding from the baseline CAD cannot be completely ruled out.

\section{Acknowledgements}

This study was supported by a grant from The American Heart Association \# $0635351 \mathrm{~N}$ awarded to Dr. Sok-Ja Janket. Dr. Meurman is supported by a grant from the Helsinki University Hospital (TYH29015109) and by a grant from the Medical Society of Finland. The funding agencies had no influence on the design and conduct of the study; collection, management, analysis, and interpretation of the data; and preparation, review, or approval of the manuscript.

\section{Conflict of Interest statement}

The authors have stated explicitly that there are no conflicts of interest in connection with this article.

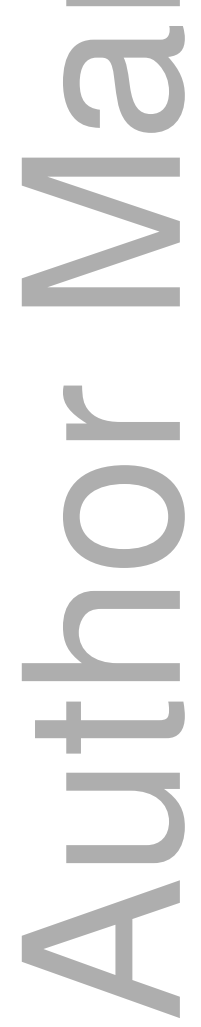

This article is protected by copyright. All rights reserved 


\section{References}

Amar J, Burcelin R, Ruidavets JB et al. (2008) Energy intake is associated with endotoxemia in apparently healthy men American Journal of Clinical Nutrition 87, 1219-23.

Bae KS, Baumgartner JC, Shearer TR, David LL (1997) Occurrence of Prevotella nigrescens and Prevotella intermedia in infections of endodontic origin Journal of Endodontics 23, 620-3.

Beck J, Garcia R, Heiss G, Vokonas PS, Offenbacher S (1996) Periodontal disease and cardiovascular disease Journal of Periodontology 67, 1123-37.

Berlin-Broner Y, Febbraio M, Levin L (2016) Association between apical periodontitis and cardiovascular diseases: a systematic review of the literature International Endodontic Journal.

Brown DW (2009) Complete edentulism prior to the age of 65 years is associated with all-cause mortality Journal of Public Health Dentistry 69, 260-6.

Bujak M, Frangogiannis NG (2009) The role of IL-1 in the pathogenesis of heart disease Archivum Immunologiae et Therapiae Experimentalis 57, 165-76.

Cabrera C, Hakeberg M, Ahlqwist M et al. (2005) Can the relation between tooth loss and chronic disease be explained by socio-economic status? A 24-year follow-up from the population study of women in Gothenburg, Sweden.[see comment] European Journal of Epidemiology 20, 229-36.

Cani PD, Amar J, Iglesias MA et al. (2007) Metabolic endotoxemia initiates obesity and insulin resistance Diabetes 56, 1761-72.

Caplan DJ, Chasen JB, Krall EA et al. (2006) Lesions of endodontic origin and risk of coronary heart disease Journal of Dental Research 85, 996-1000.

Caplan DJ, Pankow JS, Cai J, Offenbacher S, Beck JD (2009) The relationship between self-reported history of endodontic therapy and coronary heart disease in the Atherosclerosis Risk in Communities Study Journal of the American Dental Association 140, 1004-12.

Corrales-Medina VF, Musher DM, Shachkina S, Chirinos JA (2013) Acute pneumonia and the cardiovascular system Lancet 381, 496-505.

Cotti E, Dessi C, Piras A et al. (2011) Association of endodontic infection with detection of an initial lesion to the cardiovascular system Journal of Endodontics 37, 1624-9.

This article is protected by copyright. All rights reserved 
Eke PI, Page RC, Wei L, Thornton-Evans G, Genco RJ (2012) Update of the case definitions for population-based surveillance of periodontitis Journal of Periodontology 83, 1449-54.

Euler GJ, Miller GA, Hutter JW, D'Alesandro MM (1998) Interleukin-6 in neutrophils from peripheral blood and inflammatory periradicular tissues Journal of Endodontics 24, 480-4.

Garcia CC, Sempere FV, Diago MP, Bowen EM (2007) The post-endodontic periapical lesion: histologic and etiopathogenic aspects Medicina Oral, Patología Oral y Cirugía Bucal 12, E585-90.

Gomes MS, Blattner TC, Sant'Ana Filho M et al. (2013) Can apical periodontitis modify systemic levels of inflammatory markers? A systematic review and meta-analysis Journal of Endodontics 39, 1205-17. Gomes MS, Hugo FN, Hilgert JB et al. (2016) Apical periodontitis and incident cardiovascular events in the Baltimore Longitudinal Study of Ageing International Endodontic Journal 49, 334-42.

Gupta NK, de Lemos JA, Ayers CR, Abdullah SM, McGuire DK, Khera A (2012) The relationship between C-reactive protein and atherosclerosis differs on the basis of body mass index: the Dallas Heart Study $J$ Am Coll Cardiol 60, 1148-55.

Hao WR, Lin HW, Chao PZ et al. (2013) Risk of myocardial infarction in patients with rhinosinusitis Atherosclerosis 226, 263-8.

Hennekens CH, Buring JE (1987) Epidemiology in Medicine Hagerstown, MD. 21740: Lippincott Williams \& Wilkins.

Hotchkiss RS, Karl IE (2003) The pathophysiology and treatment of sepsis New England Journal of Medicine 348, 138-50.

Huumonen S, Suominen AL, Vehkalahti MM (2016) Prevalence of apical periodontitis in root filled teeth: findings from a nationwide survey in Finland International Endodontic Journal.

Inchingolo F, Marrelli M, Annibali S et al. (2014) Influence of endodontic treatment on systemic oxidative stress International Journal of Medical Sciences 11, 1-6.

Janket S, Meurman JH, Baird AE et al. (2010) Salivary immunoglobulins and prevalent coronary artery disease Journal of Dental Research 89, 389-94.

Janket SJ, Baird AE, Jones JA et al. (2014) Number of teeth, C-reactive protein, fibrinogen and cardiovascular mortality: a 15-year follow-up study in a Finnish cohort Journal of Clinical Periodontology 41, 131-40.

This article is protected by copyright. All rights reserved 
Janket SJ, Javaheri H, Ackerson LK, Ayilavarapu S, Meurman JH (2015) Oral Infections, Metabolic Inflammation, Genetics, and Cardiometabolic Diseases Journal of Dental Research 94, 119s-27s. Janket SJ, Jones JA, Meurman JH, Baird AE, Van Dyke TE (2008) Oral infection, hyperglycemia, and endothelial dysfunction Oral Surgery, Oral Medicine, Oral Pathology, Oral Radiology and Endodontics $105,173-9$.

Janket SJ, Qvarnstrom M, Meurman JH, Baird AE, Nuutinen P, Jones JA (2004) Asymptotic dental score and prevalent coronary heart disease Circulation 109, 1095-100.

Jansson L (2015) Relationship between apical periodontitis and marginal bone loss at individual level from a general population International Dental Journal 65, 71-6.

Johnson TE (1993) Factors contributing to dentists' extraction decisions in older adults Special Care in Dentistry 13, 195-9.

Joshipura KJ, Pitiphat W, Hung H-C, Willett WC, Colditz GA, Douglass CW (2006) Pulpal inflammation and incidence of coronary heart disease Journal of Endodontics 32, 99-103.

Kohler IV, Soldo BJ, Anglewicz P, Chilima B, Kohler HP (2013) Association of blood lipids, creatinine, albumin, and CRP with socioeconomic status in Malawi Popul Health Metr 11, 4.

Kornfeld OS, Hwang S, Disatnik MH, Chen CH, Qvit N, Mochly-Rosen D (2015) Mitochondrial reactive oxygen species at the heart of the matter: new therapeutic approaches for cardiovascular diseases Circulation Research 116, 1783-99.

Kouchi Y, Ninomiya J, Yasuda H, Fukui K, Moriyama T, Okamoto H (1980) Location of Streptococcus mutans in the dentinal tubules of open infected root canals Journal of Dental Research 59, 2038-46. Lee HJ, Garcia RI, Janket SJ et al. (2006) The association between cumulative periodontal disease and stroke history in older adults Journal of Periodontology 77, 1744-54.

Liljestrand JM, Mantyla P, Paju S et al. (2016) Association of Endodontic Lesions with Coronary Artery Disease Journal of Dental Research.

Love RM, Jenkinson HF (2002) Invasion of dentinal tubules by oral bacteria Critical Reviews in Oral Biology and Medicine 13, 171-83.

Miller GA, DeMayo T, Hutter JW (1996) Production of interleukin-1 by polymorphonuclear leukocytes resident in periradicular tissue Journal of Endodontics 22, 346-51.

This article is protected by copyright. All rights reserved 
Nair PN (2006) On the causes of persistent apical periodontitis: a review International Endodontic Journal 39, 249-81.

Nowjack-Raymer RE, Sheiham A (2003) Association of Edentulism and Diet and Nutrition in US adults Journal of Dental Research 82, 123 - 6.

Osterberg T, Carlsson GE, Sundh V, Steen B (2007) Number of teeth--a predictor of mortality in the elderly? A population study in three Nordic localities Acta Odontologica Scandinavica 65, 335-40.

Pasqualini D, Bergandi L, Palumbo L et al. (2012) Association among oral health, apical periodontitis, CD14 polymorphisms, and coronary heart disease in middle-aged adults Journal of Endodontics $\mathbf{3 8}$, $1570-7$.

Petersen J, GlassI EM, Nasseri P et al. (2014) The association of chronic apical periodontitis and endodontic therapy with atherosclerosis Clinical Oral Investigations 18, 1813-23.

Qvarnstrom M, Janket S, Jones JA et al. (2008) Salivary lysozyme and prevalent hypertension Journal of Dental Research 87, 480-4.

Qvarnstrom M, Janket SJ, Jones JA et al. (2010) Association of salivary lysozyme and C-reactive protein with metabolic syndrome Journal of Clinical Periodontology 37, 805-11.

Ridker PM, Buring JE, Shih J, Matias M, Hennekens CH (1998) Prospective study of C-reactive protein and the risk of future cardiovascular events among apparently healthy women.[comment] Circulation. 98, 731-3.

Savoca MR, Arcury TA, Leng X et al. (2010) Severe tooth loss in older adults as a key indicator of compromised dietary quality Public Health Nutr 13, 466-74.

Sommerfelt $H$, Steinsland $H$, van der Merwe $L$ et al. (2012) Case/control studies with follow-up: Constructing the source population to estimate effects of risk factors on development, disease, and survival Clinical Infectious Diseases 55 Suppl 4, S262-70.

Stoller EP, Pyle MA, Perzynski AT (2004) Priorities for oral health goals in a sample of older adults Special Care in Dentistry 24, 220-8.

Sugamura K, Keaney JF, Jr. (2011) Reactive oxygen species in cardiovascular disease Free Radical Biology and Medicine 51, 978-92.

This article is protected by copyright. All rights reserved 
Volpato S, Guralnik JM, Ferrucci L et al. (2001) Cardiovascular disease, interleukin-6, and risk of mortality in older women: the women's health and aging study Circulation 103, 947-53.

Zhang MM, Liang YH, Gao XJ, Jiang L, van der Sluis L, Wu MK (2015) Management of Apical Periodontitis: Healing of Post-treatment Periapical Lesions Present 1 Year after Endodontic Treatment Journal of Endodontics 41, 1020-5.

(1)
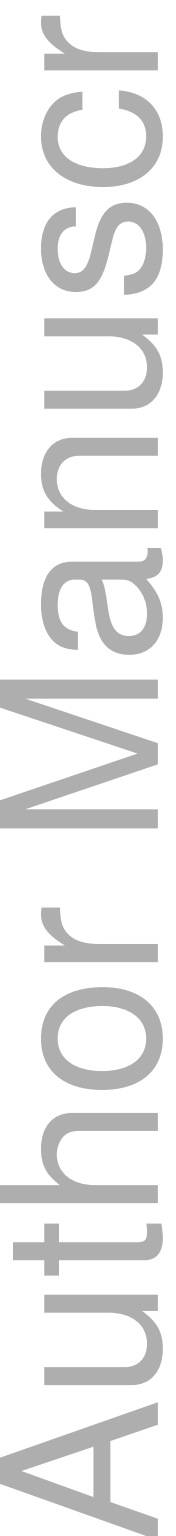

This article is protected by copyright. All rights reserved 


\section{Figure legend}

Figure 1 Age, gender, and smoking adjusted CVD survival estimates stratified by edentulism and endodontic treatment status
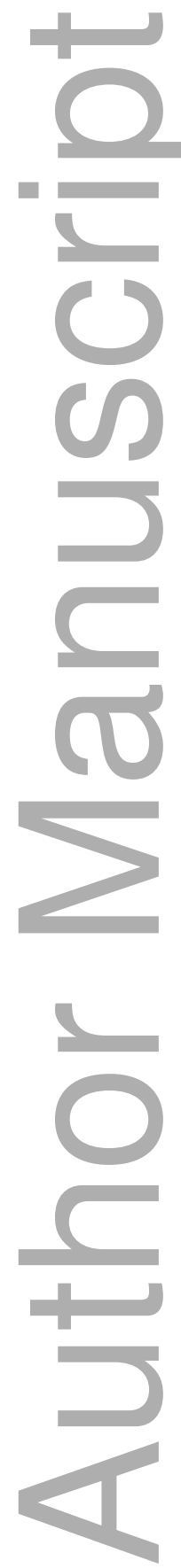

This article is protected by copyright. All rights reserved 
Table 1 Baseline characteristics of the cohort

\begin{tabular}{|c|c|c|c|}
\hline & No CAD ( $\mathrm{N}=242)$ & CAD ( $\mathrm{N}=231)$ & $p$-value \\
\hline Age, Mean (SD) & $59.3(9.8)$ & $59.9(9.1)$ & 0.5 \\
\hline $\begin{array}{c}\text { Sex }(\mathrm{N}, \%) \\
\text { Men } \\
\text { Women }\end{array}$ & $\begin{array}{l}155(64) \\
87(36)\end{array}$ & $\begin{array}{l}145(63) \\
86(37)\end{array}$ & 0.77 \\
\hline $\begin{array}{l}\text { Body Mass Index } \\
\text { (BMI) } \\
\text { Mean (SD) }\end{array}$ & $25.6(3.7)$ & $23.6(3.3)$ & $<.0001$ \\
\hline $\begin{array}{l}\text { Number of teeth } \\
\text { Mean (SD) }\end{array}$ & $15.7(10.5)$ & $7.7(10.5)$ & $<.0001$ \\
\hline $\begin{array}{l}\text { Proportion with } \\
\text { Edentulism, } \\
\mathrm{N}(\%)\end{array}$ & $36(14.9)$ & $81(35.1)$ & $<.0001$ \\
\hline Periodontitis & $54(22.3)$ & $28(12.1)$ & $<.0001$ \\
\hline $\begin{array}{l}\text { Proportion with at } \\
\text { least } 1 \text { endoTx, N (\%) }\end{array}$ & $134(53.6)$ & $37(14.5)$ & $<.0001$ \\
\hline CVD mortality, $\mathrm{N}(\%)$ & $21(8.7)$ & $69(29.9)$ & $<.0001$ \\
\hline $\begin{array}{l}\text { Education (years), } \\
\text { Mean (SD) }\end{array}$ & 11.8 ( 3.5$)$ & $10.5(2.6)$ & $<.0001$ \\
\hline $\begin{array}{l}\text { Annual Income in Euro } \\
\text { (SD) }\end{array}$ & 34058 (11525) & 31319 (9723) & 0.005 \\
\hline $\begin{array}{c}\text { Smoking, } \mathrm{N}(\%) \\
\text { Never } \\
\text { Current } \\
\text { Past } \\
\end{array}$ & $\begin{aligned} 197(81.4) \\
24(9.9) \\
21(8.7)\end{aligned}$ & $\begin{array}{l}121(52.4) \\
25(10.8) \\
85(36.8)\end{array}$ & $\begin{array}{c}0.001 \\
0.74 \\
0.0001\end{array}$ \\
\hline Hypertension, $\mathrm{N}(\%)$ & $50(20.7)$ & $115(49.8)$ & 0.001 \\
\hline Diabetes, $\mathrm{N}(\%)$ & $14(5.8)$ & $36(15.6)$ & 0.0004 \\
\hline $\begin{array}{l}\text { LDL cholesterol }^{\star} \\
\text { (mmol/L) Median† } \\
\text { (IQR) }\end{array}$ & $3.7(3.1-4.3)$ & $3.4(2.9-4.2)$ & 0.003 \\
\hline $\begin{array}{l}\text { Triglyceride }(\mathrm{mmol} / \mathrm{L}) \\
\ddagger \text { Median (IQR) }\end{array}$ & $1.5(1.2-2.0)$ & $2.0(1.4-2.6)$ & $<.0001$ \\
\hline $\begin{array}{l}\text { HDL cholesterol } \\
\text { (mmol/L)§ Median } \\
\text { (IQR) }\end{array}$ & $1.3(1.1-1.5)$ & $1.1(0.9-1.3)$ & $<.0001$ \\
\hline $\begin{array}{l}\text { Total/HDL cholesterol } \\
\text { ratio, Median (IQR) }\end{array}$ & $4.7(3.8-5.4)$ & $5.2(4.2-6.2)$ & $<.0001$ \\
\hline $\begin{array}{l}\text { CRP }(\mathrm{mg} / \mathrm{L}) \\
\text { Median (IQR) }\end{array}$ & $4.0(2-5)$ & $10((8-26)$ & $<.0001$ \\
\hline $\begin{array}{l}\text { Fibrinogen }(\mathrm{g} / \mathrm{L}) \\
\text { Median }(\mathrm{IQR})\end{array}$ & $2.9(2.6-3.2)$ & $3.1(2.8-3.7)$ & $<.0001$ \\
\hline
\end{tabular}

*LDL was estimated by Friedewald formula. †IQR: inter-quartile range. $\ddagger$ To convert $\mathrm{mmol} / \mathrm{L}$ of triglyceride to $\mathrm{mg} / \mathrm{dL}$, multiply by 88.57 . $\S$ To convert $\mathrm{mmol} / \mathrm{L}$ of cholesterol to $\mathrm{mg} / \mathrm{dL}$, multiply by 38.67 .

This article is protected by copyright. All rights reserved 
Table 2 Multivariate-adjusted odds ratios for the prevalent coronary artery disease

\begin{tabular}{|c|c|c|c|}
\hline & Exposure groups & $\begin{array}{l}\text { Odds ratio (95\% } \\
\text { confidence interval) }\end{array}$ & p-value \\
\hline Model 1 & $\begin{array}{l}\text { Edentate } \\
\text { No EndoTx* } \\
\text { EndoTx }\end{array}$ & $\begin{array}{l}1.32((0.73-2.38) \\
1 \text { (reference) } \\
0.16(0.09-0.28)\end{array}$ & $\begin{array}{l}0.36 \\
- \\
0.0001\end{array}$ \\
\hline $\begin{array}{l}\text { Confounding } \\
\text { adjusted for } \\
\text { Model } 1\end{array}$ & $\begin{array}{l}\text { Sex } \\
\text { Age } \\
\text { Smoking } \\
\text { Total/HDL cholesterol ratio } \\
\text { Hypertension } \\
\text { Diabetes } \\
\text { Income }>75 \text { percentile }\end{array}$ & $\begin{array}{l}2.35(1.33-4.14) \\
0.98(0.95-1.00) \\
3.10(2.21-4.30) \\
1.37(1.15-1.64) \\
3.57(2.14-5.98) \\
1.67(0.74-3.78) \\
1.18(0.66-2.13)\end{array}$ & $\begin{array}{l}0.003 \\
0.05 \\
<.0001 \\
<.0001 \\
<.0001 \\
0.22 \\
0.57\end{array}$ \\
\hline Model 2 & $\begin{array}{l}\text { Edentate } \\
\text { No EndoTx } \\
\text { EndoTx }\end{array}$ & $\begin{array}{l}1.21(0.66-2.23) \\
1 \text { (reference) } \\
0.17(0.10-0.29)\end{array}$ & $\begin{array}{l}0.54 \\
- \\
0.0001\end{array}$ \\
\hline $\begin{array}{l}\text { Confounding } \\
\text { adjusted for } \\
\text { Model } 2\end{array}$ & $\begin{array}{l}\text { Sex } \\
\text { Age } \\
\text { Smoking } \\
\text { Total/HDL cholesterol ratio } \\
\text { Hypertension } \\
\text { Diabetes } \\
\text { Income }>75 \text { percentile } \\
\text { Periodontitis }\end{array}$ & $\begin{array}{l}2.35(1.33-4.15) \\
0.98(0.95-1.00) \\
3.10(2.21-4.35) \\
1.37(1.15-1.64) \\
3.60(2.15-6.04) \\
1.69(0.74-3.83) \\
1.18(0.66-2.13) \\
0.82(0.42-1.61)\end{array}$ & $\begin{array}{l}0.003 \\
0.06 \\
<.0001 \\
0.0006 \\
<.0001 \\
0.21 \\
0.57 \\
0.56\end{array}$ \\
\hline Model 3 & $\begin{array}{l}\text { Edentate } \\
\text { No EndoTx* } \\
\text { EndoTx }\end{array}$ & $\begin{array}{l}1.25(0.65-2.42) \\
1 \text { (reference) } \\
0.18(0.10-0.32)\end{array}$ & $\begin{array}{l}0.50 \\
- \\
\mathbf{0 . 0 0 0 1}\end{array}$ \\
\hline $\begin{array}{l}\text { Confounding } \\
\text { adjusted for } \\
\text { Model } 3\end{array}$ & $\begin{array}{l}\text { Sex } \\
\text { Age } \\
\text { Smoking } \\
\text { Total/HDL cholesterol ratio } \\
\text { Hypertension } \\
\text { Diabetes } \\
\text { Income }>75 \text { percentile } \\
\text { Serm } C R P>3 \mathrm{mg} / \mathrm{L}\end{array}$ & $\begin{array}{l}2.63(1.45-4.77) \\
0.96(0.94-0.99) \\
3.03(2.11-4.35) \\
1.28(1.06-1.54) \\
3.43(1.97-5.98) \\
1.40(0.60-3.31) \\
1.46(0.77-2.77) \\
22.1(7.37-66.6)\end{array}$ & $\begin{array}{l}0.002 \\
0.01 \\
0.0001 \\
0.01 \\
0.0001 \\
0.44 \\
0.25 \\
0.0001\end{array}$ \\
\hline
\end{tabular}

* EndoTx: Pantomographic evidence of endodontic treatment among dentate subjects.

- All models were controlled for age, sex, smoking, hypertension, diabetes, $\mathrm{T} / \mathrm{H}$ cholesterol ratio, and income.

- Model 2 adjusted for the covariates controlled in the model 1 plus periodontitis.

- Model 3 adjusted for the covariates controlled in the model 1 plus C-reactive protein $>3 \mathrm{mg} / \mathrm{L}$.

- Bold p-values denote significance. 
Table 3 Multivariate-adjusted hazard ratios for the cardiovascular mortality

\begin{tabular}{|c|c|c|}
\hline Exposures & $\begin{array}{l}\text { Hazard ratio } \\
\text { (95\% confidence interval) }\end{array}$ & $p$-value \\
\hline $\begin{array}{l}\text { Edentate } \\
\text { No EndoTx* } \\
\text { EndoTx }\end{array}$ & $\begin{array}{l}1.27(0.77-2.11) \\
1 \text { (reference) } \\
0.51(0.27-0.97)\end{array}$ & $\begin{array}{l}0.34 \\
- \\
0.041\end{array}$ \\
\hline $\begin{array}{ll} & \text { Sex } \\
& \text { Age } \\
\text { Confounding } & \text { Smoking } \\
\text { adjusted for } & \text { Total/HDL cholesterol ratio } \\
\text { Model 1- } & \text { Hypertension } \\
& \text { Diabetes } \\
& \text { Income }>75 \text { percentile }\end{array}$ & $\begin{array}{l}0.73(0.41-1.29) \\
1.11(1.07-1.14) \\
1.54(1.18-2.02) \\
1.05(0.89-1.24) \\
1.64(1.07-2.52) \\
1.03(0.57-1.84) \\
0.71(0.39-1.30)\end{array}$ & $\begin{array}{l}0.28 \\
<.0001 \\
0.001 \\
0.59 \\
0.02 \\
0.93 \\
0.26\end{array}$ \\
\hline $\begin{array}{l}\text { Edentate } \\
\text { No EndoTx } \\
\text { EndoTx }\end{array}$ & $\begin{array}{l}1.27(0.74-2.16) \\
1 \text { (reference) } \\
0.52(0.27-0.97)\end{array}$ & $\begin{array}{l}0.38 \\
- \\
0.042\end{array}$ \\
\hline $\begin{array}{ll} & \text { Sex } \\
& \text { Age } \\
& \text { Smoking } \\
\text { Confounding } & \text { Total/HDL cholesterol ratio } \\
\text { adjusted for } & \text { Hypertension } \\
\text { Model } 2 & \text { Diabetes } \\
& \text { Income }>75 \text { percentile } \\
& \text { periodontitis }\end{array}$ & $\begin{array}{l}0.73(0.41-1.29) \\
1.11(1.07-1.14) \\
1.54(1.18-2.02) \\
1.05(0.89-1.24) \\
1.64(1.07-2.52) \\
1.03(0.57-1.86) \\
0.71(0.39-1.30) \\
0.99(0.51-1.93)\end{array}$ & $\begin{array}{l}0.33 \\
<.0001 \\
0.002 \\
0.50 \\
0.03 \\
0.91 \\
0.29 \\
0.88\end{array}$ \\
\hline $\begin{array}{ll}\text { Model } 3 & \begin{array}{l}\text { Edentate } \\
\text { No EndoTx* } \\
\text { EndoTx }\end{array}\end{array}$ & $\begin{array}{l}1.19(0.70-2.04) \\
1 \text { (reference) } \\
0.51(0.27-0.98)\end{array}$ & $\begin{array}{l}0.52 \\
- \\
\mathbf{0 . 0 4 3}\end{array}$ \\
\hline $\begin{array}{ll} & \text { Age } \\
\text { Confounding } & \text { Smoking } \\
\text { adjusted for } & \text { Total/HDL cholesterol ratio } \\
\text { Model 3 } & \text { Hypertension } \\
& \text { Diabetes } \\
& \text { Income }>75 \text { percentile } \\
& \text { Serum CRP }>3 \mathrm{mg} / \mathrm{L}\end{array}$ & $\begin{array}{l}0.75(0.42-1.34) \\
1.11(1.08-1.15) \\
1.55(1.18-2.04) \\
1.06(0.90-1.25) \\
1.60(1.04-2.46) \\
1.03(0.58-1.86) \\
0.72(0.40-1.32) \\
1.06(0.49-2.29)\end{array}$ & $\begin{array}{l}0.33 \\
<.0001 \\
0.002 \\
0.50 \\
0.03 \\
0.91 \\
0.29 \\
0.88\end{array}$ \\
\hline
\end{tabular}

* EndoTx: Pantomographic evidence of endodontic treatment among dentate subjects.

- All models were controlled for age, sex, smoking, hypertension, diabetes, $\mathrm{T} / \mathrm{H}$ cholesterol ratio, and income.

- Model 2 adjusted for the covariates controlled in the model 1 plus periodontitis.

- Model 3 adjusted for the covariates controlled in the model 1 plus C-reactive protein $>3 \mathrm{mg} / \mathrm{L}$.

- Bold p-values denote significance.

This article is protected by copyright. All rights reserved 


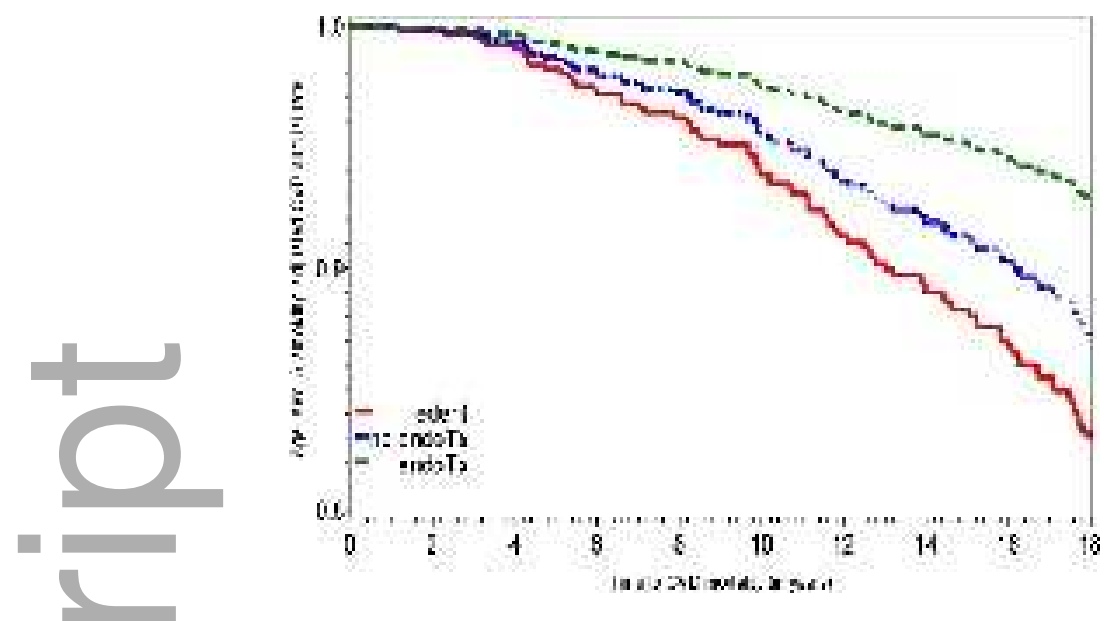

iej_12772_f1.tiff

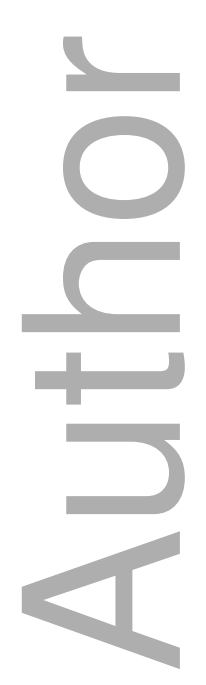

This article is protected by copyright. All rights reserved 